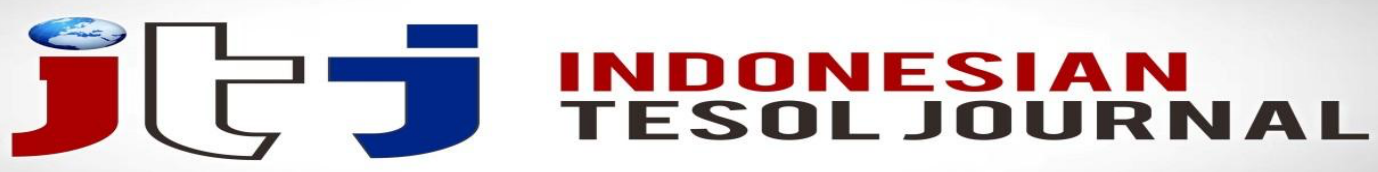

e-ISSN: 2622-5441(Online) Journal homepage: https://ejournal.iainpalopo.ac.id/index.php/ITJ/index

\title{
Pre-teaching Vocabulary in Teaching Reading Skill: A Hindrance to Learner Autonomy?
}

\author{
Takad Ahmed Chowdhury 1,2, Arjumand Ara ${ }^{2}$ \\ ${ }^{1}$ Universiti Sains Malaysia (USM), Malaysia \\ ${ }^{2}$ University of Asia Pacific (UAP), Bangladesh \\ Email:takad@uap-bd.edu
}

\begin{abstract}
Pre-teaching vocabulary of unfamiliar words of a reading or listening lesson is a technique used by English language teachers where they define and explain unfamiliar but essential words of the text just before the start of the comprehension task. Conversely, learner autonomy is an educational practice that refers to the learners' responsibility for their own learning, both in terms of what they learn and how they learn. These two diametrical ideals in English Language Teaching (ELT) demand research to justify pre-teaching vocabulary in teaching receptive language skills. Accordingly, this review paper investigated the effectiveness of pre-teaching vocabulary in teaching reading skills to English as a Second Language (ESL) or English as a Foreign Language (EFL) learners by reviewing recent literature. It sheds light on the concepts of learner autonomy, strategies to teach vocabularies in reading, pre-teaching vocabulary, and the extent pre-teaching is justified. This paper concludes that, while the principle of vocabulary pre-instruction is generally in conflict with that of learner autonomy, this particular strategy in ELT cannot be entirely disregarded to facilitate comprehension of a reading text and thus in promoting the use of target language, and can selectively be used by the teachers in interesting and useful ways. The study will help teachers to better understand to what extent pre-teaching vocabulary is useful and what strategies of this teaching technique can help motivate students to read and comprehend a reading text. Scope for future research is provided.
\end{abstract}

Keywords: learner autonomy; pre-teaching vocabulary; vocabulary selection; reading skill

\section{INTRODUCTION}

There are many reasons a strong vocabulary is critical for the success of an individual. Beck et al. (2013) reflect:

A rich vocabulary supports learning about the world, encountering new ideas, and enjoying the beauty of language. A rich vocabulary enhances an interview, allows one to see the humor in wordplay, shores up what an individual wants to say, and, especially, wants to write. It is clear that a large and rich vocabulary is the hallmark of an educated individual. Indeed, a large vocabulary repertoire 
facilitates becoming an educated person to the extent that vocabulary knowledge is strongly related to reading proficiency in particular and school achievement in general. (p. 1)

Coxhead (2021) maintains that learners with improved vocabulary in English generally have high levels of proficiency in the language. Despite the importance of vocabulary development in available research, English language educators commonly experience deficiency of vocabulary knowledge among their students (Beck et al., 2013; Coxhead, 2021; Kuder, 2017; Love, 2018). Therefore, although their learners are required to read and comprehend various reading materials in English, studies in the field generally reflect a poor reading skill of the students. The two important factors that play a major role in comprehending a reading text are adequate vocabulary and morphological awareness (Colé et al., 2018; Levesque et al., 2017). Therefore, providing rich instruction to facilitate comprehension of the learners to develop their understanding of unknown vocabulary and raise their morphological awareness becomes an essential part of their teaching responsibilities.

On the other hand, learner autonomy was originally described as the ability of the learner "to take charge of their own learning" (Holec 1981, cited in Khalifa \& Shabdin, 2016). In autonomous learning, the learner needs to take responsibility for setting their own learning objectives, outlining learning contents, choosing their techniques, monitoring, and evaluating their acquisition (Kaur, 2014). Benson (2013, cited in Tseng et al., 2020) also noted that in an autonomous learning environment, learners have control over learning management, cognitive process, and learning content. A similar idea was resonated by Little (1991, cited in Tseng et al., 2020) as he maintained that learner autonomy is a capacity for detachment, critical reflection, decision-making, and independent action. The concept of learner autonomy is a seminal contribution to the field of English Language Teaching (ELT). It has enabled the ongoing shift from teacher-centered to learner-centered approach for the past four decades. In an ideal teaching-learning environment, autonomy facilitates motivation of the learners, and their increased motivation supports them to develop their autonomy (Boyadzhieva, 2016; Chowdhury et al., 2021). Learners' motivation in their learning process guarantees higher achievements in learning (Anderman, 2020; Boyadzhieva, 2016; Green et al., 2017).

\section{THE STUDY}

While pre-teaching vocabulary, teachers introduce, explain, or define new words of a reading text to the students at the beginning of a comprehension task. This helps them understand the text better as a result of pre-learned the vocabulary. Therefore, the concepts of learner autonomy and pre-teaching vocabulary appear to be contradictory to each other, one being a learner-centered teaching principle and the other a teacher-centered method. It is therefore essential to delve into the issue 
to justify pre-teaching vocabulary in the teaching of reading skills. Accordingly, the purpose of this paper is to fill this lacuna by reviewing the effectiveness of preteaching vocabulary in teaching reading skills to ESL or EFL learners, as well as to review whether vocabulary pre-instruction impairs learner autonomy. While conducting the study, published research works from 2015 to 2021 in databases such as Google Scholar, Scopus, and Web of Science were searched for review to shed light on opposite themes. Relevant keywords were used for the article search, and inclusion and exclusion criteria were used to decide on the relevance and significance of the articles after skimming their abstracts and introduction. In addition, backward and forward snowballing helped further in finalizing the articles. All the secondary sources of data are acknowledged.

\section{PRE-TEACHING VOCABULARY}

Pre-teaching vocabulary is an instructional method employed by the teachers to ease comprehension of a reading text by the students. The increased morphological awareness achieved by learning unfamiliar words allows the learners' cognitive function to focus on understanding the text without being distracted by decoding the meaning of new words. This technique is employed by the teachers to help their students create a 'vocabulary fluency' for spontaneity and accuracy in understanding the text by making a connection between vocabulary and comprehension. Beck et al. (2013) noted that understanding the meanings of individual words makes comprehension of a reading text easier. When a learner stops interpreting a reading text to determine word meanings or meaning units, it inhibits the skill of the short-term brain and hinders a thorough understanding of the text (Mousavian \& Siahpoosh, 2018b). Laufer (1996, cited in Past, 2019) directly associates reading comprehension with vocabulary understanding claiming that lexis is the best predictor of reading comprehension, far more so than syntax or general reading skills and techniques. Vocabulary pre-instruction provides learners with the chance to be familiarized with the difficult words before reading a text and thus supports them in understanding. Unfamiliar vocabulary is a major impediment to comprehension of a text and use of the language (Nation, 2013, cited in Ballance, 2018). Therefore, research evidence is clear about the benefits of pre-teaching vocabulary in efficient understanding of the reading text and to perform better in comprehension tasks (Alamri \& Rogers, 2018; Hilgenkamp, 2019; Mousavian \& Siahpoosh, 2018b; Past, 2019).

\section{VOCABULARY SELECTION CRITERIA}

To promote effectiveness in vocabulary instruction, different criteria are used to whittle down word lists for teaching depending on their contexts such as frequency, usefulness and difficulty (He \& Godfroid, 2019; Laufer \& Nation, 2012) or importance, transferability to other disciplines, and usefulness for generative studies (Graves, 2006; Stahl \& Nagy, 2006 cited in Johnston, 2007). Balance (2018) maintains that evaluating the usefulness of a word in terms of its frequency in a language or within a discourse domain, or its importance to the learner's learning goals and context of language use provides a solid basis for vocabulary selection for pre-teaching. Therefore, the broader principle that can be followed in the selection of words to pre-teach vocabulary for a reading lesson is, distinguishing between essential and inessential vocabulary. The teacher can categorize the words 
or expressions learners need to understand that are more useful to achieve their learning goals, more frequent in the language or in the discipline of their study, and their level of difficulty into the essential vocabulary. Similarly, the other words even when they are unknown can fall into the category of inessential vocabulary in the particular teaching context. Therefore, the essential new words of the reading text are introduced and pre-taught by the teacher to facilitate vocabulary development and comprehension. The idea is to promote an effective and productive use of the language (Ballance, 2018) through the use of pre-learned vocabulary. Thus, it is essential for the teacher to clearly understand their reason for including the vocabulary pre-teaching component within a lesson and select the words to be taught based on this justification.

\section{BENEFITS OF PRE-TEACHING VOCABULARY}

Ballance (2018) recapped the two main reasons for pre-teaching vocabulary as the lexical resource deficit rationale and the vocabulary learning and improvement rationale. The benefits of pre-teaching essential vocabulary are manifold:

Firstly, reading appears to be intimidating to the students who fail to cultivate a good reading habit because of their lexical resource deficit. Pre-teaching vocabularies help them understand the unknown lexical items in a text, leading to comprehension of the whole reading text, reducing their fear, and increasing their interest in reading.

Secondly, pre-teaching of essential words from a reading text helps the learners apply their cognitive faculties to predict the content of the text they are about to read, and thus helps them become more engaged with the text.

Thirdly, looking through the meaning after reading a text might fail to intellectually appeal to a reader of a genre that requires the readers' imagination. They may not be able to get involved, unfold their imagination, or understand how ideas are ordered in a piece of poem when they come across too many unfamiliar words while reading it.

Fourthly, pre-teaching vocabulary enhances the chance for the learners to achieve their learning objective of understanding the writer's viewpoint and using the target language more comfortably by providing them extra support when a text becomes daunting with advanced vocabulary.

Fifthly, pre-teaching vocabulary contributes to both the teachers' and students' convenience by developing fluency and interest in reading activities, who are required to complete a certain number of lessons within their allotted class time.

Finally, the very nature of a text may sometimes require vocabulary for preteaching. To give an example, the following extract may be considered for teaching in an EFL or ESL class of pre-intermediate level English proficiency:

\section{Ernest Hemingway's Iceberg Theory}

The Iceberg Theory is the writing style of American writer Ernest Hemingway. Influenced by his journalistic career, Hemingway contended that by omitting 
superfluous and extraneous matter, writing becomes more interesting. When he became a writer of short stories, he retained this minimalistic style, focusing on surface elements without explicitly discussing the underlying themes. Hemingway believed the true meaning of a piece of writing should not be evident from the surface story, rather, the crux of the story lies below the surface and should be allowed to shine through. Critics such as Jackson Benson claim that his iceberg theory, also known as the theory of omission, in combination with his distinctive clarity of writing, functioned as a means to distance himself from the characters he created.

Hemingway summarizes his theory as follows:

If a writer of prose knows enough of what he is writing about he may omit things that he knows and the reader, if the writer is writing truly enough, will have a feeling of those things as strongly as though the writer had stated them. The dignity of movement of an ice-berg is due to only one-eighth of it being above water. A writer who omits things because he does not know them only makes hollow places in his writing. - Ernest Hemingway in 'Death in the Afternoon.

(Extracted from MyEnglishPages.com, n.d.)

The passage refers to a style of writing followed by an American novelist, short-story writer, and journalist. Hence, learners without some familiarity with literary prose may have problems in understanding it well. The text also includes words like 'superfluous', 'extraneous', 'minimalistic' etc. that may be unfamiliar and difficult to students but are crucial for understanding the text. Moreover, these words are not only important in grasping the text, but also frequent and useful in the discourse domain, i.e., writing style in general.

In sum, pre-teaching of words that are difficult, useful, and relevant to the domain discourse is found to be beneficial in comprehension of a reading text, because it engages the learners in achieving their learning objectives. Therefore, findings from numerous studies endorsing this technique come as no surprise (Alamri \& Rogers, 2018; Ballance, 2018; Hilgenkamp, 2019; Mousavian \& Siahpoosh, 2018b; Past, 2019). However, the importance of clearly identified rationale for the inclusion of this step within a lesson and selection of words to be pre-taught cannot be overstated (Ballance, 2018).

\section{STRATEGIES FOR PRE-TEACHING VOCABULARY}

Instead of explicitly providing word meanings or asking the students what an essential word from a reading text means, presentation of meanings of potentially challenging words by using possible alternative ways is more effective. Therefore, strategies for pre-teaching vocabulary depend on individual teachers' level of expertise, their creativity, and the level of their students. Some strategies of vocabulary teaching as stated by Brewster, Ellis, and Girard (1992, cited in Alqahtani, 2015) include:

a) Using real objects, visual aids, and demonstration

b) Drawing the object

c) Using illustrations and pictures

d) Providing synonyms or antonyms 
e) Supplying examples of the kind

f) Using mime, expressions, and gestures

g) Inspiring guesswork by providing a context

h) Eliciting

i) Providing translation

Moreover, creating mnemonic keywords, a technique that combines identification of a keyword and use of imagery to establish a powerful retrieval route, has also been identified to improve learning of foreign language vocabulary (Miyatsu \& McDaniel, 2019). In addition, a study conducted by Hilgenkamp (2019) noted that using available online resources through internet technology by the students themselves to search for definitions of the words and then reviewing them during the reading task can help them learn and review unfamiliar vocabulary. He offered a chart where students recorded keywords (ideas), information (definition), and memory clues about unknown scientific words upon collecting them for retention and understanding a scientific text. In addition, Kabilan and Zahar (2016) recommend using social networking site Facebook as a supplementary learning environment to create a community of practice to enhance vocabulary through engaging and collaborative activities, particularly in a non-classroom setting. Teachers may use one or multiple strategies to pre teach vocabulary.

However, although successful pre-teaching of essential vocabulary facilitates comprehension of a reading text, repeated exposure to those unfamiliar words in meaningful context can only ensure their acquisition. Therefore, rich and varied language experiences of the learner play a key role in vocabulary retention.

\section{IS PRE-TEACHING VOCABULARY A NECESSITY?}

While the benefits of pre-teaching vocabulary have been established by several studies (for example, Alamri \& Rogers, 2018; Ballance, 2018; Hilgenkamp, 2019; Mousavian \& Siahpoosh, 2018b; Past, 2019), some teachers find it unnecessary noting that this particular strategy is against the principles of learner autonomy. They consider that pre-teaching vocabulary deals with pre-empting problems rather than training learners how to deal with the problems. Supporting the concept of developing learner autonomy in vocabulary learning in EFL/ESL classrooms, Haddad (2016) argues that learners who are self-dependent in vocabulary acquisition grow their ability to succeed academically and are more motivated than those who do not develop effective vocabulary learning strategies by themselves. Fard \& Vakili (2018) demonstrated that increased cognitive engagement with content can substantially promote development of vocabulary among EFL learners. Janitra (2020) found that self-regulated vocabulary learning strategies can positively impact both learner autonomy and vocabulary development among the learners where they learn vocabulary in a more flexible and independent environment outside the classrooms than during their classroom activities.

Moreover, setting a context to introduce essential but unknown vocabulary from a reading text before introducing the reading task is challenging for a teacher. A lesson without a context may curve their motivation and induce boredom among the learners. On the other hand, a reading text helps the learners encounter new words in meaningful contexts and enables them to learn these words by linking 
them with useful and interesting content. Therefore, if the lesson can evoke their interest, learners are likely to feel motivated to find the meaning out themselves. Besides, readers often infer meanings of some words when they understand the context and some vital information of the text. Thus, they can sometimes grasp the global meaning of a text even without being preteaught the essential vocabulary. Learners get a feeling of satisfaction when they can handle a text as a whole. Equipping learners with the skill of dealing with difficult reading text can foster learner autonomy.

Green (1981, cited in Budiharso, 2014) proposed five instructional activities during a reading lesson to maximize interaction of the readers to a text and to increase comprehension. These are:

a) Identifying the main idea, where the readers discover the key concept of the text and try to give a title or select the most appropriate title, and identify topic sentences through skimming.

b) Finding details in a text, where readers try to find specific information in the text through scanning.

c) Following a sequence by relating events or items in a particular order or process.

d) Inferring from the text by trying to understand the text using their schemata and experience.

e) Recognizing the discourse patterns by applying all their linguistic and nonlinguistic knowledge to understand the text holistically.

\section{A FINAL REFLECTION}

Although 'self-directed learning', the basic maxim of learner autonomy appears conflicting to a teacher-centric teaching strategy like pre-teaching vocabulary, the benefits of vocabulary pre-instruction cannot be denied, especially when there is a clear rationale, a careful selection of essential words to pre-teach, and a well-designed teaching plan (Ballance, 2018). This is the reason Nation (2008, cited in Past, 2019) recommended that a small amount of vocabulary may be necessary to pre-teach in a reading activity to enhance comprehension. However, the teacher should be guided by the principle of introducing the essential words in an interactive, creative, and motivating way following a well-designed teaching plan, when the vocabulary load in the target text necessitates pre-teaching some vocabulary.

\section{CONCLUSION}

This study attempted to justify pre-teaching vocabulary in teaching reading skills in the EFL or ESL context. While casting light on the effectiveness of this technique, this paper reviewed the concepts of learner autonomy, strategies to teach and pre-teach vocabulary and the extent pre-teaching can be justified. It can be concluded from the study that while the concept of pre-teaching vocabulary seems to be at odds with that of learner autonomy, the role of this technique cannot be overlooked in enhancing comprehension of a reading text. Therefore, vocabulary pre-teaching can be selectively used by the teachers through interesting, motivating, and effective teaching techniques. One of the main purposes of ELT is to prepare 
students to deal with many linguistic experiences that emerge in everyday life by teaching them not only how to understand the words in a given context, but also how to use them effectively and responsibly. Hence, pre-teaching vocabulary should be considered if there is a properly established rationale. However, it is relevant to note here that, in planning their lessons teachers need to consider that effectiveness of their lesson counts on some principles, such as lesson management, lesson structure, students' motivation to study, and class size (Velikaya, 2020).

Finally, the study is significant as it adds to the body of literature on a pertinent issue in the ELT context. It aspires to lead the way for future researchers in conducting empirical studies to validate the outcome of this paper.

\section{ACKNOWLEDGMENTS}

The authors like to thank Professor Dr. Muhammad Kamarul Kabilan, School of Educational Studies, Universiti Sains Malaysia and Associate Professor Dr. Naginder Kaur, Academy of Language Studies, Universiti Teknologi MARA, Perlis Branch, Malaysia. Discussion with her encouraged them to conduct this study.

\section{REFERENCES}

Alamri, K., \& Rogers, V. (2018). The effectiveness of different explicit vocabularyteaching strategies on learners' retention of technical and academic words. Language Learning Journal, 46(5), 622-633. https://doi.org/10.1080/09571736.2018.1503139

Alqahtani, M. (2015). The importance of vocabulary in language learning and how to be taught. International Journal of Teaching and Education, III(3), 21-34. https://doi.org/10.20472/te.2015.3.3.002

Anderman, E. M. (2020). Achievement motivation theory: Balancing precision and utility. Contemporary Educational Psychology, 61(April), 101864. https://doi.org/10.1016/j.cedpsych.2020.101864

Ballance, O. J. (2018). Strategies for Pre-Teaching Vocabulary in Context. In The TESOL Encyclopedia of English Language Teaching (1st Edit, pp. 1-6). John Wiley \& Sons, Inc. https://doi.org/10.1002/9781118784235.eelt0732

Beck, I. L., McKeown, M. G., \& Kucan, L. (2013). Rationale for Robust Vocabulary Instruction. In Bringing Words to Life (2nd ed.). The Gulford Press.

Boyadzhieva, E. (2016). Learner-centered Teaching and Learner Autonomy. Procedia - Social and Behavioral Sciences, 232(April), 35-40. https://doi.org/10.1016/j.sbspro.2016.10.008

Budiharso, T. (2014). Reading Strategies in Efl Classroom: a Theoretical Review. CENDEKIA: Journal of Education and Teaching, 8(2), 189-204. https://doi.org/10.30957/cendekia.v8i2.63

Chowdhury, T. A., Roy, S., \& Kabilan, M. K. (2021). Learner motivation in the EFL classrooms: Voices from a Bangladeshi university. Indonesian Journal 
of Applied Linguistics, 221-232. https://doi.org/10.17509/ijal.v11i1.34618

Colé, P., Cavalli, E., Duncan, L. G., Theurel, A., Gentaz, E., Sprenger-Charolles, L., \& El-Ahmadi, A. (2018). What is the influence of morphological knowledge in the early stages of reading acquisition among low SES children? A graphical modeling approach. Frontiers in Psychology, 9(APR), 1-15. https://doi.org/10.3389/fpsyg.2018.00547

Coxhead, A. (2021). Vocabulary in English in Tertiary Contexts : Connecting Research and Learning. LEARN Journal: Language Education and Acquisition Research Network Journal, 14(1), 1-14. https://so04.tcithaijo.org/index.php/LEARN/index

Fard, E. E., \& Vakili, A. (2018). The Effect of Problem-Based Learning on Iranian EFL Learners' Vocabulary Learning. The Journal of Asia TEFL, 15(1), 208216. http://dx.doi.org/10.18823/asiatefl.2018.15.1.15.208

Green, P. I., Finkel, E. J., Fitzsimons, G. M., \& Gino, F. (2017). The energizing nature of work engagement: Toward a new need-based theory of work motivation. Research in Organizational Behavior, 37, 1-18. https://doi.org/10.1016/j.riob.2017.10.007

Haddad, R. H. (2016). Developing Learner Autonomy in Vocabulary Learning in Classroom: How and Why can it be Fostered? Procedia - Social and Behavioral Sciences, 232(April), 784-791. https://doi.org/10.1016/j.sbspro.2016.10.106

He, X. (Stella), \& Godfroid, A. (2019). Choosing Words to Teach: A Novel Method for Vocabulary Selection and Its Practical Application. TESOL Quarterly, 53(2), 348-371. https://doi.org/10.1002/tesq.483

Hilgenkamp, J. A. (2019). How Does Pre-teaching of Vocabulary and the Use of Technology Increase Student Learning in Science [University of Nebraska Linkoln]. https://digitalcommons.unl.edu/teachlearnstudent Part

Janitra, T. I. (2020). Exploring autonomous and self-regulation in vocabulary learning. Jurnal Penelitian, Pendidikan, Dan Pembelajaran, 15(28), 1-15. http://riset.unisma.ac.id/index.php/jp3/article/view/7449

Johnston, F. (2007). How to Select Words for Vocabulary Instruction Criteria for Selection. Https://Assets.Pearsonschool.Com. https://assets.savvas.com/asset_mgr/current/201640/Francine_ArticleForRes earch.pdf

Kabilan, M. K., \& Zahar, T. Z. M. E. (2016). Enhancing students' vocabulary knowledge using the Facebook environment. Indonesian Journal of Applied Linguistics, 5(2), 217-230. https://doi.org/10.17509/ijal.v5i2.1346

Kaur, N. (2014). Autonomous Language Learning Behaviour: The Role of Instructional Mediation in Vocabulary Development. Pertanika Journal of Social Science and Humanities, 22(2), 589-603. 
Khalifa, S., \& Shabdin, A. (2016). Autonomy in Vocabulary Learning: Vocabulary Learning Strategies Teaching Programme for EFL Libyan Learners. Arab World English Journal, 7(1), 140-159. https://doi.org/10.24093/awej/vol7no1.10

Kuder, S. J. (2017). Vocabulary Instruction for Secondary Students with Reading Disabilities: An Updated Research Review. Learning Disability Quarterly, 40(3), 155-164. https://doi.org/10.1177/0731948717690113

Laufer, B., \& Nation, I. S. P. (2012). Vocabulary. In S. M. Gass \& A. Macke (Eds.), The Routledge handbook of second language acquisition (pp. 163-176). Routledge. https://doi.org/10.4324/9780203808184.ch10

Levesque, K. C., Kieffer, M. J., \& Deacon, S. H. (2017). Morphological awareness and reading comprehension: Examining mediating factors. Journal of Experimental Child Psychology, 160, 1-20. https://doi.org/10.1016/j.jecp.2017.02.015

Love, M. (2018). Promoting Vocabulary Knoweldge In Inclusive Science Classrooms: Comparison Of Instructional Methods [University of Nevada, Las Vegas]. http://dx.doi.org/10.34917/14139885

Miyatsu, T., \& McDaniel, M. A. (2019). Adding the keyword mnemonic to retrieval practice: A potent combination for foreign language vocabulary learning? Memory and Cognition, 47(7), 1328-1343. https://doi.org/10.3758/s13421019-00936-2

Mousavian, S., \& Siahpoosh, H. (2018a). Global Journal of Foreign Language Teaching. Global Journal of Foreign Language Teaching, 8(3), 94-103. scholar.google.com

Mousavian, S., \& Siahpoosh, H. (2018b). The Effects of Vocabulary Pre-teaching and Pre-questioning on Intermediate Iranian EFL Learners' Reading Comprehenstion Ability. International Journal of Applied Linguistics and English Literature, 7(2), 58. https://doi.org/10.7575/aiac.ijalel.v.7n.2p.58

MyEnglishPages.com. (n.d.). Reading Comprehension - Ernest Hemingway's Iceberg Theory. Retrieved January 29, 2021, from https://www.myenglishpages.com/site_php_files/reading-ernest-hemingwaystyle.php

Past, T. (2019). Pre-Teaching Vocabulary for Improving Reading Comprehension. Temple University Japan Studies in Applied Linguistics, 122, 37-46. scholar.google.com

Tseng, W. T., Liou, H. J., \& Chu, H. C. (2020). Vocabulary learning in virtual environments: Learner autonomy and collaboration. System, 88, 1-17. https://doi.org/10.1016/j.system.2019.102190

Velikaya, E. V. (2020). The challenges and opportunities of creating an effective lesson at tertiary level. Indonesian TESOL Journal, 2(2), 116-127. https://doi.org/10.24256/itj.v2i2.1346 